\title{
An Investigation into the Prospects of Green Building Practice in Nigeria
}

\author{
D. Dahiru ${ }^{1}$, A. A. Dania ${ }^{1,2} \&$ A. Adejoh ${ }^{1}$ \\ ${ }^{1}$ Department of Building, Ahmadu Bello University, Zaria, Nigeria \\ ${ }^{2}$ Department of Construction Management, University of Reading, U.K. \\ Correspondence: D. Dahiru, Department of Building, Ahmadu Bello University, Zaria, Nigeria. Tel: \\ 234-80-2260-1115. E-mail:daudadahiru509@gmail.com
}

Received: October 22, 2013 Accepted: September 14, 2014 Online Published: November 23, 2014

doi:10.5539/jsd.v7n6p158 URL: http://dx.doi.org/10.5539/jsd.v7n6p158

\begin{abstract}
Green Building (GB) is a concept that gains currency as an important mitigating measure against the negative side effects of developmental activities. This is a report on investigation carried out on the prospects of GB practice in Nigeria. This research work entails review of related literature to establish the concept of GB, problems militating against the practice of GB and method of constructing GB. A total of 50 structured questionnaires were distributed, out of which 40 were received. Practice of GB in Nigeria, factors hindering the practice and benefits of GB were investigated. Based on Likert scale ranking, results show that GB is currently not practiced and the need for it exist. Also, lack of awareness is the most prominent factor hindering the construction of GB, followed by 'Lack of enabling environment in the form of policy or legislation that will encourage prospective clients to use GB and 'Economic situation of the country'. Health and productivity gain is identified as the most important benefit of green building, followed by 'preservation of natural resources while taking care of their health' and 'attraction and retention of employee'. It was recommended that public enlightenment should be done by Non Governmental Organizations, government and professional bodies, the practice of Green building should be encouraged by the government, request for construction environmental management plan from contractors as part of tender documents and the government should liaise with the industry's stakeholders to establish a construction bank that will empower the people.
\end{abstract}

Keywords: environmental degradation, sustainability, green building, mitigating measures, preservation

\section{Introduction}

Human activities on the environment, to meet his daily needs, exert pressure on the environment. For instance, construction activities which are regarded as the heart of every development constitute a powerful influence on the environment. The construction industry consumes a major share of resources and produces a commensurate share of waste. According to Agenda 21 for sustainable construction, in Dahiru (2005), the industry is often referred to as the 40 per cent industry as it is responsible for the consumption of approximately 40 percent of natural resources and about 40 per cent of all waste produced. Dimson (1998) in Gandu (2005) observed that human habitats (buildings) contribute to environmental crises through resources depletion, energy consumption, air pollution and creation of waste. Ajatar (2000) outlines up to ten different adverse effects of construction activities on the environment. These include, among others, land misuse, existing site dereliction, habitat destruction, misuse of natural resources, etc.

Additionally, the on-site construction practices result in a number of health and comfort disturbances, especially to people living around such areas, where construction activities are taking place. One problem which is of great concern is the observation made by Schmidt (2000) that building activities are responsible for approximately one-third of ecological disasters. Thus, it can be seen, clearly, that construction activities have direct impact on man and his environment, as it leads to the change in the state or condition of such environment in terms of not only the quality but also the stock of natural resources. One important question that should be addressed is: "how can we ensure that these activities (construction activities) do not compromise the ability of future generations in achieving their needs.

According to Kolawole \& Anigbogu (2005), the friendliest way to handle the environment is not to build. 
However, without construction, life can be miserable and threatening. For shelter is needed, among other things, for protection against the inclement weather and for healthy living. Kolawole \& Anigbogu (2005) opined that what is needed is a dynamic equilibrium. In other words, production process that is friendly to the ecosystem, yet competitive and possesses no any form of threat (Lardered, 1988). Environmentally friendly buildings, popularly called Green Buildings (GB), sustainable or high-performance buildings, seem to satisfy the above mentioned requirements.

This is a report on the study carried out on the problems and prospects of Green construction practice in Nigeria. The following are the objectives of the research:

1) To establish through literature, the events or circumstances that bring about the concept of GB and find out whether such conditions exist in Nigeria.

2) To articulate the concept and principles of GB.

3) Identify the important requirements for a structure to be qualified as a GB

4) To find out whether such buildings are constructed in the construction industry in Nigeria

5) To identify the factors militating against the practice and prospects or benefits of GB

\section{Research Methods}

The research design employed for this work was the descriptive survey in which lecturers in higher Institutions, professionals in the construction industry in Nigeria and the prospective beneficiaries of such services (GB) were randomly selected. The areas covered in this research are: The Federal Capital Territory, FCT, Abuja, Kaduna and Kano States,

The main research instrument used was a well-structured questionnaire containing closed ended questions with suggested answers measured in a Likert Scale. Interview with some of the respondents was also carried out.

A total of 50 questionnaires were distributed, out of which 40 were returned and used for analysis. The questionnaire solicited information on the Practice, Problems and Prospects of Green Building in Nigeria from the various respondents based on their experiences. The views sampled include; respondents understanding of Green construction practice, Professionals in the Green Building design team and their numbers, problems of Green Building practice, benefits derived from Green Building, level of importance attached to the benefits and level of awareness of the concept of Green Building in Nigeria.

\section{Data Presentation and Analysis}

The data obtained is presented and analyzed as follows:

\subsection{Design Team}

One important feature of GB is that all the people that will take part in the construction of GB must be part of the design team, so as to achieve synergistic design, as such; the study was targeted at the members of this team. The breakdown is presented in Tables 1 and 2:

Table 1. Distribution of questionnaires

\begin{tabular}{ll}
\hline Number distributed & $\mathbf{5 0}$ \\
\hline Number properly completed and returned & 40 \\
Percentage response & $80 \%$ \\
\hline
\end{tabular}

Source: Field Survey (2012) 
Table 2. Profession of respondents

\begin{tabular}{lccc}
\hline Profession & No. Distributed & No. of Response & \% of Response \\
\hline Architects & 11 & 8 & 73 \\
Builders & 15 & 15 & 100 \\
Engineers & 7 & 5 & 71 \\
Quantity Surveyor & 7 & 5 & 71 \\
Town planners & 6 & 4 & 67 \\
Estate Surveyors & 4 & 3 & 75 \\
Total & 50 & 40 & \\
\hline
\end{tabular}

Source: Field Survey (2012)

Table 2 shows a breakdown of the questionnaires from 40 respondents. Architects returned 73\%, Builders 100\%, Engineers 71\%, Quantity Surveyor 71\%, Town Planners 67\% and Estate Surveyors 75\%.

\subsection{Need for Green Building in Nigeria}

The study sought to establish, whether there are serious side effects of developmental activities in the environment that would call for the practice of GB in Nigeria. Table 3 shows the results of such findings:

Table 3. Construction activities have negative impact in the environment in Nigeria

\begin{tabular}{lcc}
\hline Response & Number of Response & Percentage of Response \\
\hline Yes & 38 & $95 \%$ \\
No & 2 & $5 \%$ \\
Total & 40 & $100 \%$ \\
\hline
\end{tabular}

Source: Field Survey (2012)

The results in table 3 shows that $95 \%$ of respondents were of the view that condition calling for the use of GB do exist in Nigeria while only 5\% said "No". This clearly shows that the need for mitigating measures

\subsection{Site Selection}

Another important condition for the construction of GB is that the site selected for such building should be the one that is in worst condition not best like Brownfield - abandoned industrial sites, Infill - building on a vacant site within an established urban area. The study sought to find out if Professionals were involved in the construction of building on such type of site.

Table 4. Compliance with criterion for selecting construction site for green building in Nigeria

\begin{tabular}{lcc}
\hline Response & Number of Response & Percentage of Response \\
\hline Yes & 7 & $13 \%$ \\
No & 33 & $87 \%$ \\
Total & 40 & $100 \%$ \\
\hline
\end{tabular}

Source: Field Survey (2012)

Table 4 shows that $87 \%$ of the respondents said "No" (Disagree) that deliberate effort is made to select construction sites that are in worst condition in order to construct GB While 13\% said "Yes" (agree). This shows that one criterion for the construction of GB has not been fulfilled.

\subsection{Synergistic Design}

Another very important condition for the practice of GB is that the design is the result of input of each and every 
person involved in order to achieve synergy. As such, respondents were asked whether they were opportune to work as members of a team in the design of GB. The result of the investigation is presented in table 4

Table 5. Participation in the production of the synergistic design

\begin{tabular}{lcc}
\hline Response & Number of Response & Percentage of Response \\
\hline Yes & 2 & $5 \%$ \\
No & 38 & $95 \%$ \\
Total & 40 & $100 \%$ \\
\hline
\end{tabular}

Source: Field Survey (2012)

The result in table 5 shows that $95 \%$ of the professionals have not participated in the production of design as a team. While only 5\% indicated that they participated. This shows that majority of the respondents have not actually participated in the design of GB.

\subsection{Factors Militating against the Construction of GB}

Some factors militating against the construction of GB as obtained from the literature (Means, 2004) were presented to the respondents and they were asked to rank them based on their importance. The result is presented in Table 4.

Table 6. Factors hindering the practice of green building

\begin{tabular}{|c|c|c|c|c|c|c|c|c|}
\hline \multirow[t]{2}{*}{$\mathbf{s} / \mathbf{n}$} & \multirow[t]{2}{*}{ Factors } & \multicolumn{4}{|c|}{$\begin{array}{l}\text { Frequency } \\
\text { Responses }\end{array}$} & \multirow[t]{2}{*}{$\Sigma \mathrm{f}$} & \multirow[t]{2}{*}{$\Sigma f \mathrm{x}$} & \multirow{2}{*}{$\begin{array}{l}\text { Mean } \\
\left(\mathrm{x}^{\prime}\right)\end{array}$} \\
\hline & & 1 & 2 & 3 & 4 & & & \\
\hline 1. & Lack of awareness. & - & 7 & 15 & 18 & 40 & 131 & 3.28 \\
\hline 2. & $\begin{array}{l}\text { Developers and builders tend to keep things as simple as } \\
\text { possible. }\end{array}$ & 11 & 14 & 8 & 4 & 37 & 79 & 2.14 \\
\hline 3. & Market expectation. & 5 & 15 & 8 & 9 & 37 & 95 & 2.57 \\
\hline 4. & No enabling environment & 3 & 17 & 3 & 16 & 39 & 95 & 3.00 \\
\hline 5. & Economic situation & - & 5 & 15 & 20 & 40 & 120 & 3.00 \\
\hline 6. & Lack of professionals to handle the task. & 11 & 14 & 5 & 5 & 35 & 74 & 2.11 \\
\hline 7. & Lack of technical know-how & 10 & 13 & 11 & 1 & 35 & 73 & 2.09 \\
\hline
\end{tabular}

Source: Field Survey (2012)

1=Not important; $2=$ Less important; 3=Important; 4= Very Important

Table 6 shows responses on the factors hindering the practice of Green Building in Nigeria, on a scale of 1 to 4 ranging from Not important to Very Important. The result shows that the factor which regards GB as a relatively new trend (lack of awareness) averaged 3.28, meaning the respondents regards it as important problems of Green Building practice. Developers and Builders tend to keep things as simple as possible 2.14 (less important). Lack of technical know-how averaged 2.09 meaning less important also. This shows that the respondents have different opinions on the factors hindering the practice of Green Building.

3.6 Prospects of $G B$

The prospect of GB was assessed by asking the respondents to rank the benefit of GB 
Table 7. Benefits derived from green building (prospects)

\begin{tabular}{|c|c|c|c|c|c|c|c|c|}
\hline \multirow{2}{*}{$\mathbf{s} / \mathbf{n}$} & \multirow{2}{*}{ Factors } & \multicolumn{4}{|c|}{ Frequency Responses } & \multirow{2}{*}{$\Sigma \mathrm{f}$} & \multirow{2}{*}{$\Sigma \mathrm{fx}$} & \multirow{2}{*}{ Mean $\left(x^{\prime}\right)$} \\
\hline & & 1 & 2 & 3 & 4 & & & \\
\hline 1. & It reduced capital cost & - & - & 10 & 30 & 40 & 150 & 3.75 \\
\hline 2. & It reduced operating cost & - & - & 11 & 27 & 38 & 141 & 3.71 \\
\hline 3. & $\begin{array}{l}\text { Market benefits (free pass and product } \\
\text { differentiation) }\end{array}$ & - & - & 10 & 30 & 40 & 150 & 3.75 \\
\hline 4. & Health and productivity gain & - & - & 5 & 35 & 40 & 155 & 4.00 \\
\hline 5. & It reduced liability risk & - & - & 20 & 20 & 40 & 140 & 3.50 \\
\hline 6. & Attracting and retaining employees & - & - & 8 & 30 & 38 & 144 & 3.79 \\
\hline 7. & Waste management & - & - & 16 & 23 & 39 & 140 & 3.59 \\
\hline 8. & Preserving natural resources & - & - & 5 & 35 & 40 & 155 & 3.88 \\
\hline 9. & Satisfaction from doing the right thing & - & - & 11 & 29 & 40 & 149 & 3.73 \\
\hline
\end{tabular}

Source: Field Survey (2012)

$1=$ strongly Disagree; $2=$ Disagree; $3=$ Agree $; 4=$ strongly agree .

Table 7 shows responses from the questionnaire on the benefits derived from Green Building on a scale of 1 to 4 ranging from strongly disagree to strongly agree. "It reduced capital cost of building", averaged 3.75 meaning that the respondents have strongly agreed that GB there are benefit derived from the construction of GB." It reduced operating cost of the building", averaged 3.71 (strongly agree)."Market benefits" (free pass and product differentiation) averaged 3.75 (strongly agree). It averaged 3.50 (strongly agree). "Attracting and retaining or employees within the building" (employments opportunity), averaged 3.79 (strongly agree). "It controls waste management during and after construction of the building," averaged 3.59 (agree)." It helps in preserving natural resources," averaged 4.00 (strongly agree). While "total satisfaction from doing the right thing," averaged 3.73 (strongly agree). This indicates that the respondents agree, strongly, to all the benefits of Green Building.

\section{Summary of Results}

The study found that:

1) Conditions necessitating the need for Green Buildings exist in Nigeria.

2) Majority of the respondents (95\%) have not participated in the design of GB: this implies

3) that they did not participate in the construction of Green Building, there is no compliance with site selection criterion for the construction of GB as $13 \%$ of the respondents noted that sites that are in worst condition are rehabilitated, while $87 \%$ said they did not take part in any rehabilitation of construction site for GB

4) Out of the various problems that GB has, as outlined by Means (2004), the most important one militating against the practice of GB, are lack of awareness (3.28) and no enabling environment and economic situation (3.00)

5) All the benefits outlined in the questionnaire were seen as very important The most important benefits are Health and productivity gain (4.00), followed by preserving natural resources (3.88) and reduction of operating cost (3.79), while, attracting and retaining employees (3.75).

\section{Oral Interviews}

Oral interviews with some professionals were conducted in an attempt to ascertain other problems affecting Green Building practice in Nigeria as well as benefits derived from Green Building practice .Other issues that were not sufficiently covered in the questionnaire were also part of the questions asked in the interviews like the curricula of Department of Building in the Universities and Polytechnics and the issue of an enabling environment for the practice of GB The result of the interview are as follows:

\subsection{Some Problems of Green Building Practice in Nigeria}

1) No Enabling Environment: The result of investigation shows that there is no enabling environment in the form of policy, legislation or some form of incentives for the practice of GB.Quite unlike what is obtained in the 
developed nations in which government lead by example - through the construction of some public building using the concept of GB.

2) Uncertain Economic Environment: In Nigeria, the private sector has a narrow market base and the formal construction industry overly relies on the government for work, whose work orders fluctuate with income giving volatile oil pricing in the international market. There has also been a reduction in public spending as services previously provided by government are being privatized due to fiscal prudence. These have brought about fluctuation in construction activities which discourage long term strategic planning, which in turn hinders access to investment capital. Delays with interim and final payments, as well as onerous contract conditions faced by construction firms can also impose huge constraints on the industry. According to Osanga\&Apochi (2000), in Dahiru (2009) many indigenous firms have suffered financial ruin and bankruptcy because of delays in payments, which are common with government contracts.

3) Technological Barriers: Technology dependency hinders the autonomous development of indigenous technology. Nigeria needs knowledge and technology that are better adapted to its natural resources than those which are obtained from industrialized countries. For example, the use of earth and timber construction that predated colonialism has been abandoned and no longer popular.

4) Lack of Integrated Research: Much of the research in building technologies and planning is not done in a holistic approach. The research institutions, development agencies and other organizations address each issue individually and independently of other issues to which it is linked.

5) Lack of Interest in the Issue of Sustainability: There is a general lack of interest in the issues of sustainability by the construction sector, its clients and other stakeholders. This negligence is experienced differently through the various stakeholders such as:

a. Politicians: Environmental Sustainability issues rarely constitute agenda differentiation of political parties or political leadership, except as occasioned by the recent protests in the Niger-Delta of the country.

b. Local Authorities: It never forms any requirements for their plan approvals, land use or land sub-division. Local Authorities do not request EIA plan of Environmental Impact Statement (EIS) as a criterion to plans approval. The construction industry is traditionally very indifferent to change, especially when it comes to the construction methods and building materials used.

c. No Enlightenment Campaign on GB: Not much effort has been made on public enlightenment regarding GB.

\subsection{GB in the Curriculums of Some Courses in the Universities and Polytechnics}

Result of interviews with lecturers' shows that the current syllabus of sustainable construction (Green Building) taught in our higher institutions of learning (Universities and Polytechnics) is inadequate to enable the practice Green Building (Design and Construction Phase) effectively. Also, not much has been done on the issue of research work.

\subsection{Conditions That Necessitate the Need for GB}

Results of the interview and search or study of relevant Literatures such as Kolawole\&Anigbogu (2005), Mbamalli (2005) and Gandu (2005) agrees with the results of field survey which show that the conditions that call for GB exist in Nigeria. Considering the fact that there is a substantial environmental damage not only from construction work but also from oil exploration. In Nigeria

\section{Conclusions and Recommendations}

\subsection{Conclusion}

In this study an attempt was made to gauge the perception of professionals in the built environment as regard to the respect of GB in Nigeria. First the concept of GB was closely examined - the roles of each professionals involved, processes involved in design and construction of GB and its benefits. This was followed by a preparation of a checklist of the important criterion that buildings must satisfy for it to be qualified as GB. This was used to determine whether or not GB concept is been used in the building industry in Nigeria; effort was also made to establish the existence of conditions calling for GB and the respondents' view on prospect of GB in Nigeria. Based on the results the following conclusions were arrived at.

GB is not practiced in Nigeria; there is no any enabling environment in the form of legislation or policy on Green Building practice; the overall perception of Green Building from all the groups of respondents has revealed, that most professionals are aware of the new trend (Green Building) and enormous benefits derived 
from it and they see Green Building as a basis for appealing livable homes and preserving natural resources while taking care of their health. However, the general public are not fully aware of this development i.e. level of awareness of Green Building is low.

There is no adequate provision in the current syllabus of some courses in the tertiary institutions on the construction of GB in tertiary institutions in Nigeria.

\subsection{Recommendations}

Based on the results obtained in this research, the following are recommended.

1) Public enlightenment should be done by government and professional bodies through Continuing Professional Development (CPD). Non - Governmental Organization, NGO should also assist in this respect through enlightenment campaign.

2) The practice of Green Building should be encouraged by the government requesting for Construction Environmental Management Plan from contractors as part of tender documents.

3) The government should, in cooperation with the industry's professional bodies and private individuals establish a construction bank that will empower the economic situation.

4) Designers should adopt a more integrated approach to design and appreciate the fundamentals of Green Buildings.

5) Manufacturers of construction materials should use life cycle considerations as the basis of product development and should cooperate with designers in the development environmentally friendly construction materials. Also, they should form partnerships with research firms by providing funds for research and development and implementation.

6) Government should lead by example through the construction of GB for major public buildings and provide incentive for those that want to construct GB

7) The major corporations operating in the country, most especially oil companies should be encouraged to use the concept of GB in the construction of their major offices. They should also sponsor researches on GB.

8) Part of the Community's Social Responsibility (CSR) undertaken by corporate bodies, especially Oil companies, should be provision of schools, clinics, libraries, community hall, etc , made of GB

\section{References}

Ajatar, U. (2000). Project Impacts and Mitigation - A challenge for Nigerian Construction Practioners in the $3^{\text {rd }}$ Millennium. Environmental Review, 3(2), 343-349.

Dahiru, D. (2005). Measures of Ensuring Sustainability in the Nigerian Construction Industry. A Paper Presented at the $2^{\text {nd }}$ National Conference Towards Sustainable Built Environment.Ahmadu Bello University, Zaria - Nigeria. Sept. $21^{\text {st }}-23^{\text {rd }}$.

Dahiru, D. (2009). Building Construction Lecture Notes. Department of Building, Ahmadu Bello University, Zaria - Nigeria.

Gandu, J. (2005). Environmental Management Tools for Sustainable Development. A Paper Presented at the National Conference Towards a Sustainable Built Environment.Ahmadu Bello University, Zaria - Nigeria. Sept. $21^{\text {st }}-23^{\text {rd }}$.

Glasson, J. et al. (2001). Introduction to Environmental Impact Assessment. UCL Press Ltd, London, U.K.

Karolides, A. (2002). "Green Building Approaches" in Green Building: Project Planning \& Cost Estimatin., RS Means Co Ltd; USA Pp $1-22$.

Kolawole, J., \& Anigbogu (2005). Impact of Construction Activities on the Environment. A Paper Presented at the $2^{\text {nd }}$ National Conference Towards a Sustainable Built Environment.Ahmadu Bello University, Zaria Nigeria. Sept. $21^{\text {st }}-23^{\text {rd }}$.

Lardered, J. A. (1998). Environmental Management Tool for Sustainable Development. Environmental Engineering International Perspectives.

Mbamali, I. (2005). Stone Quarrying in Nigeria: An Overview on Necessary Indicatives towards a Sustainable Built Environment. Conference Proceedings of the $2^{\text {nd }}$ National Conference tagged: "Towards a Sustainable Built Environment." Ahmadu Bello University, Zaria. $21^{\text {st }}-23^{\text {rd }}$ September.

Means, R. S. (2002). Green Building Project Planning and Cost Estimating (1st ed.). Reed Construction Data 
Publisher, London, U.K.

Schmidt. (2000). Towards Healthy and Environmentally Oriented Construction Practices in Ukraine Housing Environment. Umbruch. pp. 250-256.

\section{Appendix A}

\section{Questionnaire}

Department of Building,

Faculty of Environmental Design,

Ahmadu Bello University, Zaria, Nigeria.

Dear respondent,

This questionnaire is being administered for a research in Building Department, Ahmadu Belle University, and Zaria. It is designed to gather relevant and prevailing information on the problems and prospects of Green Building practice in Nigeria.

All information given would be treated confidentially and strictly used for academic purposesonly.

\section{SECTION A; (Personal Data)}

1. Name of respondent (Optional)

2. Years of experience in building construction (please tick as appropriate)

( ) 0-5years ( ) 5-10 years ( ) 10-15 years ( ) 15 years above

3. Profession (kindly tick)

( ) Architecture ( ) Building ( ) Engineering ( ) Quantity surveying

Others, (kindly specify).

4. Job designation / post.

5. Highest qualification obtained (kindly tick)

( ) Ordinary National Diploma (OND) ( ) Higher National Diploma (HND)

( ) Bachelor's Degree (B.Sc) ( ) Masters Degree (M.Sc)

( ) Doctorate Degree (PhD) Others (please state).

\section{SECTION B (Green Building)}

1. Do you know that construction activities have negative impacts on the environment?
( ) Yes
( ) No

2. How would you rate the level of impacts above?

( ) very low ( ) low ( ) moderate ( ) high ( ) very high

3. The adverse effects of construction activities resulted to: (select all that apply)

( ) Health and safety impairment ( ) Waste / effluent discharges

( ) Energy consumption ( ) Misused of natural resources ( ) Land misuse (erosion, desertification).
4. Do you think these problems can be solved? ( ) Yes
( ) No

5. In your own view, what is the solution?

( ) Sustainability Others (please specify).....

6. It is important to carryout Environmental Impact Assessment (EIA) on any project development before its execution? () Yes ( ) No

7. Below are some reasons for EIA. Please indicate the level of importance attached to the reasons, on scale (1 -4) by ticking the correct option.

Notimportant, 1 Less important-2, Important-3, Very important -4 .

\begin{tabular}{|l|l|l|l|l|l|}
\hline S/N & Reasons & 1 & 2 & 3 & 4 \\
\hline 1 & Can lead to environmental sensitive development. & & & \\
\hline
\end{tabular}




\begin{tabular}{|l|l|l|l|l|}
\hline 2 & An instrument for sustainable development. & & & \\
\hline 3 & Provide systematic examination of the environmental implication on the project. & & & \\
\hline 4 & Aid to formulation of development actions. & & & \\
\hline 5 & To predict the nature and magnitude of proposed action and its effects. & & & \\
\hline 6 & To document the indicators to be used in assessing the impact. & & & \\
\hline 7 & To give confidence to the planning system. & & & \\
\hline
\end{tabular}

8. Are you aware of any legislation governing die practice of EIA in Nigeria?

( ) Yes ( ) No

9. If yes in (Q8) above, please specify......

10. Green Building has been defined in divers ways, in your own opinion GB is?

( ) Environmentally Friendly Building ( ) improving the building users health through reduction of toxic materials ( ) total quality approach to building. ( ) A holistic approach to programming, planning, designing, and constructing (or renovating) building and sites.

11. Is Green Building (GB) practice in Nigeria? ( ) Yes ( ) No

12. If No, state reasons (please tick)

( ) Construction and maintenance cost of Green Building. ( ) lack of awareness

() lack of interest ( ) others (please specify).

13. Below are some factors hindering the practice of Green Building in Nigeria? Please indicate the level of importance you attached to these factors on scale (1-4) by ticking the appropriate option.

Not important - 1, Less important - 2, Important - 3, Very important - 4.

\begin{tabular}{|l|l|l|l|l|l|}
\hline S/N & Factors & 1 & 2 & 3 & 4 \\
\hline 1 & It's relatively a new trend (lack of awareness). & & & & \\
\hline 2 & Developers and Builders tend to keep things as simple as possible. & & & & \\
\hline 3 & Market expectation. & & & & \\
\hline 4 & No enabling environment. & & & & \\
\hline 5 & Economic situation. & & & & \\
\hline 6 & Lack of professionals to handle the task. & & & & \\
\hline 7 & Lack of technical know How. & & & & \\
\hline
\end{tabular}

14. The following professionals made up the Design team for Green Building. Please indicate your level of importance attached to these members, on scale $(1-5)$ by ticking the appropriate option.

Neutral-1, Not important- 2, Less important- 3, Important-4, Very important- 5 .

\begin{tabular}{|l|l|l|l|l|l|l|}
\hline S/N & PROFESSIONALS & 1 & 2 & 3 & 4 & 5 \\
\hline 1 & Developers/ Owner/ Client & & & & & \\
\hline 2 & Architect & & & & & \\
\hline 3 & Surveyor & & & & & \\
\hline 4 & Town Planner & & & & & \\
\hline 5 & Engineers ( Mechanical, Electrical, and Services ) & & & & & \\
\hline 6 & Quantity Surveyor & & & & & \\
\hline 7 & Builder & & & & & \\
\hline 8 & Estate Surveyor and Valuer's & & & & & \\
\hline
\end{tabular}




\begin{tabular}{|l|l|l|l|l|l|l|}
\hline 9 & Consultancies & & & & & \\
\hline 10 & Commissioning Agent & & & & & \\
\hline
\end{tabular}

15. Qualities of materials used for the construction of Green Building are listed below Please indicate the level of importance you attached to them, on scale (1-4) by ticking the appropriate option.

Not important-1, Less important- 2, Important- 3, Very 1 nportant-4.

\begin{tabular}{|l|l|l|l|l|l|}
\hline S/N & QUALITIES OF MATERIALS & 1 & 2 & 3 & 4 \\
\hline 1 & Are healthy for the natural environment & & & & \\
\hline 2 & Are healthy for the interior environment & & & & \\
\hline 3 & Help minimizing building energy use & & & & \\
\hline 4 & Have low - embodied energy & & & & \\
\hline 5 & Are durable, reusable, recyclable, and biodegradable. & & & \\
\hline 6 & Are locally obtained or sourced. & & & & \\
\hline 7 & $\begin{array}{l}\text { Resource efficient and will not compromise the health of (the } \\
\text { environment /occupant. }\end{array}$ & & & \\
\hline
\end{tabular}

16. Do you think Green Building can deliver some benefits to Nigeria if practiced? ( )Yes ( )No

17. If yes, what benefits are derived from Green Building practices? (Select all that apply).

( ) Reduced capital cost ( ) Reduced operating cost ( ) Market benefits (free press and product differentiation). ( ) Health and productivity gain. ( ) New business opportunities) Attracting and retaining employees. ( ) Reduced liability risk. () Satisfaction from doing the right thing.

18. Please indicate the level of importance you attached to the following benefits of Green Building practice if employed in Nigeria, on scale ( $\mathrm{J}-4)$ by ticking the appropriate option.

Not Important -1, Less Important -2, Important -3, Very Important -4.

\begin{tabular}{|l|l|l|l|l|l|}
\hline S/N & BENEFITS & 1 & 2 & 3 & 4 \\
\hline 1 & Economic- Financial benefits & & & & \\
\hline 2 & Health and social & & & & \\
\hline 3 & Environmental -preserving natural resources. & & & & \\
\hline
\end{tabular}

\section{Copyrights}

Copyright for this article is retained by the author(s), with first publication rights granted to the journal.

This is an open-access article distributed under the terms and conditions of the Creative Commons Attribution license (http://creativecommons.org/licenses/by/3.0/). 